\title{
Front Matter: Volume 10229
}

, "Front Matter: Volume 10229," Proc. SPIE 10229, Photon Counting Applications 2017, 1022901 (12 June 2017); doi: 10.1117/12.2281901

SPIE. Event: SPIE Optics + Optoelectronics, 2017, Prague, Czech Republic 


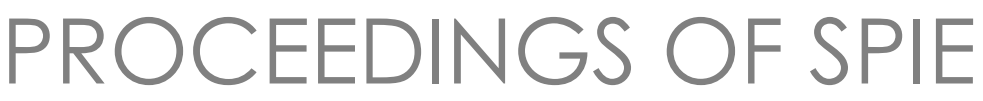

\title{
Photon Counting Applications 2017
}

\author{
Ivan Prochazka \\ Roman Sobolewski \\ Ralph B. James \\ Editors
}

24-25 April 2017

Prague, Czech Republic

Sponsored by

SPIE

Cooperating Organisations

Science and Technology Facilities Council (United Kingdom)

ELI Beamlines (Czech Republic)

Laserlab Europe

AILU-Association of Laser Users (United Kingdom)

European Optical Society

HiLASE (Czech Republic)

AWE-Atomic Weapons Establishment (United Kingdom)

Published by

SPIE 
The papers in this volume were part of the technical conference cited on the cover and title page. Papers were selected and subject to review by the editors and conference program committee. Some conference presentations may not be available for publication. Additional papers and presentation recordings may be available online in the SPIE Digital Library at SPIEDigitalLibrary.org.

The papers reflect the work and thoughts of the authors and are published herein as submitted. The publisher is not responsible for the validity of the information or for any outcomes resulting from reliance thereon.

Please use the following format to cite material from these proceedings:

Author(s), "Title of Paper," in Photon Counting Applications 2017, edited by Ivan Prochazka, Roman Sobolewski, Ralph B. James, Proceedings of SPIE Vol. 10229 (SPIE, Bellingham, WA, 2017) Seven-digit Article CID Number.

ISSN: 0277-786X

ISSN: 1996-756X (electronic)

ISBN: 9781510609594

ISBN: 9781510609600 (electronic)

Published by

SPIE

P.O. Box 10, Bellingham, Washington 98227-0010 USA

Telephone +1 3606763290 (Pacific Time) · Fax +1 3606471445

SPIE.org

Copyright @ 2017 , Society of Photo-Optical Instrumentation Engineers.

Copying of material in this book for internal or personal use, or for the internal or personal use of specific clients, beyond the fair use provisions granted by the U.S. Copyright Law is authorized by SPIE subject to payment of copying fees. The Transactional Reporting Service base fee for this volume is $\$ 18.00$ per article (or portion thereof), which should be paid directly to the Copyright Clearance Center (CCC), 222 Rosewood Drive, Danvers, MA 01923. Payment may also be made electronically through CCC Online at copyright.com. Other copying for republication, resale, advertising or promotion, or any form of systematic or multiple reproduction of any material in this book is prohibited except with permission in writing from the publisher. The CCC fee code is 0277-786X/17/\$18.00.

Printed in the United States of America.

Publication of record for individual papers is online in the SPIE Digital Library.

\section{SPIE. DIGRARY}

Paper Numbering: Proceedings of SPIE follow an e-First publication model. A unique citation identifier (CID) number is assigned to each article at the time of publication. Utilization of CIDs allows articles to be fully citable as soon as they are published online, and connects the same identifier to all online and print versions of the publication. SPIE uses a seven-digit CID article numbering system structured as follows:

- The five digits correspond to the SPIE volume number.

- The last two digits indicate publication order within the volume using a Base 36 numbering system employing both numerals and letters. These two-number sets start with 00, 01, 02, 03, 04, 05, 06, 07, 08, 09, OA, OB ... OZ, followed by 10-1Z, 20-2Z, etc. The CID Number appears on each page of the manuscript. 


\title{
Contents
}

\author{
$\checkmark \quad$ Authors \\ vii Conference Committee \\ ix Introduction
}

SUPERCONDUCTING PHOTON COUNTING I

1022903 Superconducting nanowire single-photon detectors: recent advances (Invited Paper) [10229-2]

\section{SOLID STATE PHOTON COUNTING AND ITS APPLICATIONS I}

10229 OA High-performance integrated pick-up circuit for SPAD arrays in time-correlated single photon counting (Invited Paper) [10229-9]

10229 OB High-efficiency dynamic routing architecture for the readout of single photon avalanche diode arrays in time-correlated measurements [10229-10]

10229 OC Photon counting detector package optimized for laser time transfer with sub-picosecond limiting precision and stability [10229-11]

10229 OD Development of a high-performance multi-channel system for time-correlated single photon counting [10229-12]

10229 OE Development and characterization of an 8x8 SPAD-array module for gigacount per second applications [10229-13]

\section{SUPERCONDUCTING PHOTON COUNTING II}

10229 OG Coherent detection of weak signals with superconducting nanowire single photon detector at the telecommunication wavelength (Invited Paper) [10229-15]

$10229 \mathrm{OH}$ Superconducting order parameter fluctuations in NbN/NiCu and NbTiN/NiCu bilayer nanostripes for photon detection [10229-16]

10229 ol Investigation of dark counts in innovative materials for superconducting nanowire single-photon detector applications [10229-17]

\section{SOLID STATE PHOTON COUNTING AND ITS APPLICATIONS II}

10229 oJ Satellite laser ranging in the near-infrared regime (Invited Paper) [10229-18] 
10229 OK Satellite and lunar laser ranging in infrared [10229-19]

$10229 \mathrm{OL}$ Evaluation of performance of silicon photomultipliers in LIDAR applications [10229-20]

$10229 \mathrm{ON}$ Ultra-high optical responsivity of semiconducting asymmetric nano-channel diodes for photon detection [10229-22]

POSTER SESSION

10229 OP An ultra-fast thermoelectric sensor for single-photon detection in a wide range of the electromagnetic spectrum [10229-24]

$102290 Q$ Tracks detection from high-orbit space objects [10229-25]

10229 OR Short-range energy budget simulator of single photon lidar demonstrator [10229-26]

10229 OS Time transfer capability of standard small form factor pluggable laser modules based on photon counting approach [10229-27] 


\section{Authors}

Numbers in the index correspond to the last two digits of the seven-digit citation identifier (CID) article numbering system used in Proceedings of SPIE. The first five digits reflect the volume number. Base 36 numbering is employed for the last two digits and indicates the order of articles within the volume. Numbers start with 00, 01, 02, 03, 04, 05, 06, 07, 08, 09, OA, OB...0Z, followed by 10-1Z, 20-2Z, etc.

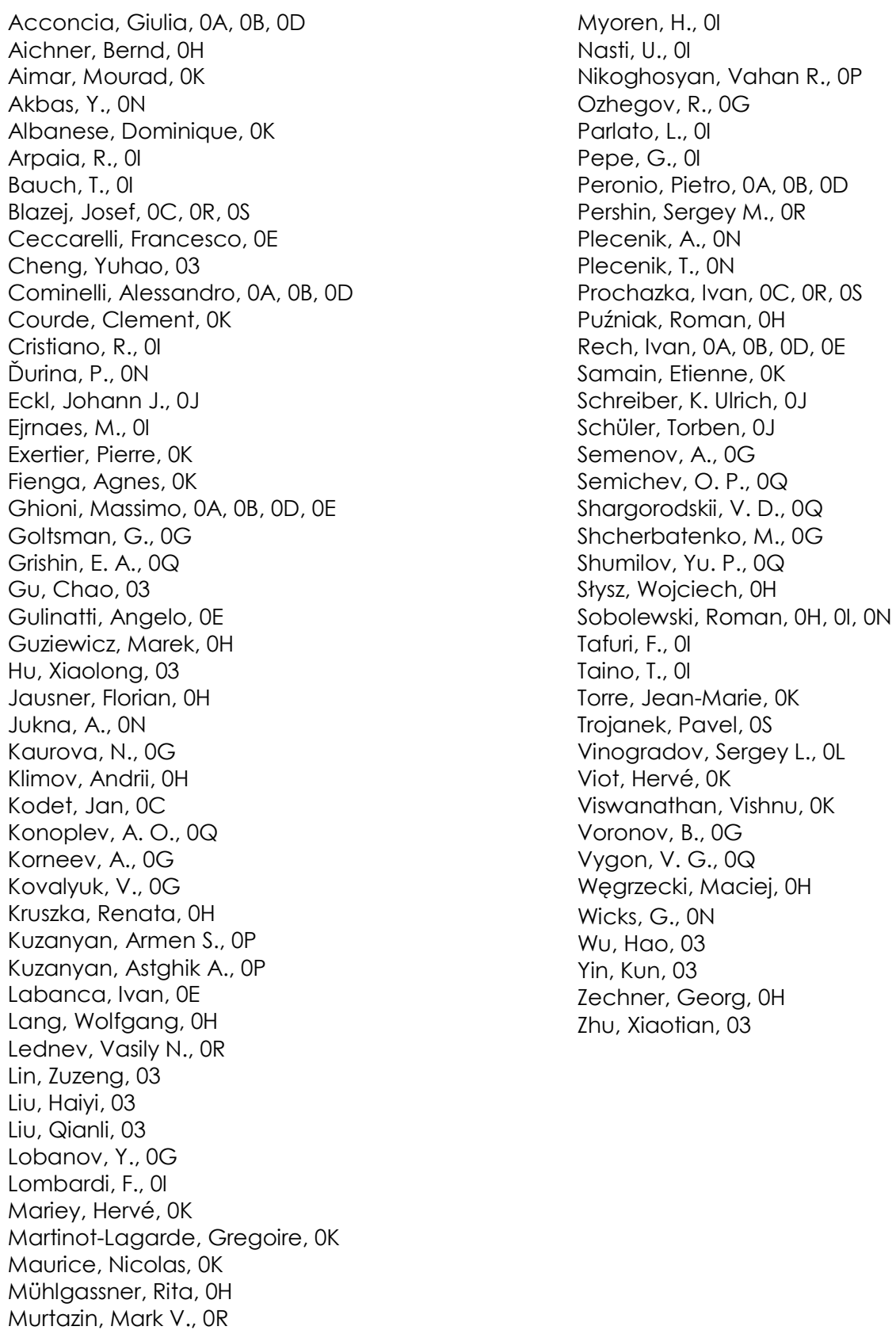

Myoren, $\mathrm{H}$., $\mathrm{Ol}$

Nasti, U., $\mathrm{Ol}$

Nikoghosyan, Vahan R., OP

Ozhegov, R., OG

Parlato, L., Ol

Pepe, G., 이

Peronio, Pietro, OA, OB, OD

Pershin, Sergey M., OR

Plecenik, A., ON

Plecenik, T., ON

Prochazka, Ivan, OC, OR, OS

Puźniak, Roman, $\mathrm{OH}$

Rech, Ivan, OA, OB, OD, OE

Samain, Etienne, OK

Schreiber, K. Ulrich, OJ

Schüler, Torben, 0J

Semenov, A., OG

Semichev, O.P., $O Q$

Shargorodskii, V. D., OQ

Shcherbatenko, M., OG

Shumilov, Yu. P., OQ

Słysz, Wojciech, $\mathrm{OH}$

Sobolewski, Roman, $\mathrm{OH}, \mathrm{OI}, \mathrm{ON}$

Tafuri, F., 0

Taino, T., $\mathrm{Ol}$

Torre, Jean-Marie, OK

Trojanek, Pavel, OS

Vinogradov, Sergey L., OL

Viot, Hervé, OK

Viswanathan, Vishnu, OK

Voronov, B., OG

Vygon, V. G., OQ

Węgrzecki, Maciej, $\mathrm{OH}$

Wicks, G., ON

Wu, Hao, 03

Yin, Kun, 03

Zechner, Georg, $\mathrm{OH}$

Zhu, Xiaotian, 03 
Proc. of SPIE Vol. 10229 1022901-6

Downloaded From: https://www.spiedigitallibrary.org/conference-proceedings-of-spie on 26 Apr 2023 Terms of Use: https://www.spiedigitallibrary.org/terms-of-use 


\title{
Conference Committee
}

\author{
Symposium Chairs
}

Jiri Homola, Institute of Photonics and Electronics of the ASCR, v.v.i. (Czech Republic)

Bedrich Rus, Institute of Physics of the ASCR, v.v.i. (Czech Republic)

Chris Edwards, Central Laser Facility, Science and Technology Facilities Council (United Kingdom)

Mike Dunne, SLAC National Accelerator Laboratory (United States) and Linac Coherent Light Source (United States)

Ivo Rendina, Istituto per la Microelettronica e Microsistemi, CNR (Italy)

\section{Conference Chairs}

Ivan Prochazka, Czech Technical University in Prague

(Czech Republic)

Roman Sobolewski, University of Rochester (United States)

Ralph B. James, Savannah River National Laboratory (United States)

\section{Conference Programme Committee}

Josef Blazej, Czech Technical University in Prague (Czech Republic)

Ulrich Schreiber, Technische Universität München (Germany)

Valery Zwiller, KTH Royal Institute of Technology (Sweden)

\section{Session Chairs}

1 Superconducting Photon Counting I

Roman Sobolewski, University of Rochester (United States)

2 X-ray Photon Detection

Aleksey E. Bolotnikov, Brookhaven National Laboratory (United States)

3 Solid State Photon Counting and Its Applications I

Ivan Prochazka, Czech Technical University in Prague

(Czech Republic)

4 Superconducting Photon Counting II

Oleg A. Mukhanov, HYPRES, Inc. (United States)

5 Solid State Photon Counting and Its Applications II

Josef Blazej, Czech Technical University in Prague (Czech Republic) 
Proc. of SPIE Vol. 10229 1022901-8

Downloaded From: https://www.spiedigitallibrary.org/conference-proceedings-of-spie on 26 Apr 2023 Terms of Use: https://www.spiedigitallibrary.org/terms-of-use 


\section{Introduction}

This volume contains the proceedings of the SPIE Conference on Photon Counting Applications. The conference was held on 24-25 April, in Prague, Czech Republic as part of SPIE Optics and Optoelectronics 2017. The meeting was organized into technical sessions on superconducting photon counting, X-ray photon detection, and solid-state photon counting and applications. A poster session was also featured.

The purpose of the conference was to provide a forum for scientists and engineers from the detector development and user communities to present and evaluate the most recent results on photon-counting detectors and to discuss the requirements for a variety of detection and imaging applications. A total of 24 presentations, including four posters, were presented at the conference. This book provides detailed documentation describing a portion of the presentations. The editors hope that it will serve as an important record of the meeting, provide an update on the status of photon-counting detectors and applications, and serve as a useful resource for those working in the field.

The Conference Chairs would like to thank the Session Chairs and members of the Conference Programme Committee, who offered their time to enlist the involvement of researchers working in the field. 
Proc. of SPIE Vol. 10229 1022901-10 Downloaded From: https://www.spiedigitallibrary.org/conference-proceedings-of-spie on 26 Apr 2023
Terms of Use: https://www.spiedigitallibrary.org/terms-of-use 